\author{
Michael D. Bordo \\ Anna J. Schwartz \\ Working Paper 8717 \\ http://www.nber.org/papers/w8717
NATIONAL BUREAU OF ECONOMIC RESEARCH
1050 Massachusetts Avenue
Cambridge, MA 02138 \\ January 2002
}

Prepared for the Festschrift in Honour of Charles Goodhart, Bank of England. Conference Centre, 15-16 November 2001. The views expressed herein are those of the authors and not necessarily those of the National Bureau of Economic Research.

(C) 2002 by Michael D. Bordo and Anna J. Schwartz. All rights reserved. Short sections of text, not to exceed two paragraphs, may be quoted without explicit permission provided that full credit, including (C) notice, is given to the source. 
Charles Goodhart's Contributions to the History of Monetary Institutions

Michael D. Bordo and Anna J. Schwartz

NBER Working Paper No. 8717

January 2002

JEL No. E58, G18, G21

\begin{abstract}
Our paper examines Charles Goodhart's work on the history of monetary institutions: central bank operations under the gold standard, their behaviour in relation to the financial system in which they functioned, including their responses to banking crises, and their performance as lenders of last resort. Although we differ with Charles on some of the conclusions that he has reached, we pay tribute to his importance in shaping the discussion by economists over a thirty-year span on questions related to the functioning of banks, their customers, and the historic central banks that evolved from serving government to serving banks.
\end{abstract}

Michael D. Bordo

Department of Economics

New Jersey Hall

Rutgers University

New Brunswick, NJ 08901-1284

and NBER

bordo@fas-econ.rutgers.edu
Anna J. Schwartz

NBER

365 Fifth Avenue

5th Floor

New York, NY 10016-4309

aschwartz@gc.cuny.edu 


\section{Charles Goodhart's Contributions to the History of Monetary Institutions}

\section{Introduction}

The focal point of Charles Goodhart's research studies has undoubtedly been the evolution of central banks. He has offered reasons for the rise of the central bank institution and analysed its operation from the $19^{\text {th }}$ century on, particularly during the gold standard era. Subjects that he has investigated include not only how central bank conduct of monetary policy has changed over the decades but also their relation to the financial systems that they headed. He has paid particular attention to their role as lenders of last resort. Another paper at this conference will deal with Charles's studies of central bank monetary policies. Our paper examines his work on the history of monetary institutions: central bank operations under the gold standard, their behaviour in relation to the financial system in which they functioned, including their responses to banking crises, and their performance as lenders of last resort.

Charles has compared the origins and structure of at least eight European central banks as well as of the Bank of Japan at the end of the $19^{\text {th }}$ century with corresponding features of the Bank of England. He has also summarised the objectives and functions of 32 central banks, listed in chronological order of their founding, beginning with the Sveriges Riksbank the forerunner of which was founded in 1668, and ending with the Central Bank of Uruguay founded in 1967. It is, however, the Bank of England that he has been most intimate with, so it is not surprising that his main contributions to the study of monetary institutions revolve about the Bank's operations.

As important as central banking has been to Charles's research interests, it does not exhaust them. He has studied monetary regimes with no central bank, such as regimes with currency boards. In fact, he has had more than an academic relation to the Hong Kong experience; he has also been an adviser to its government. In addition, he has examined with an open mind the claims for free banking that would deny the need for a central bank. 
We begin with a review of the work that Charles published as a fledgling Ph.D.(section 2). His subject was the gold standard, the rules of the game for the Bank of England, the role of commercial banks, financial crises, and the need for a lender of last resort. We then go on to discuss the highlights of his research as a mature scholar. The main subject is the evolution of central banks from government banks to bankers' banks to independent central banks (section 3). We report Charles's analysis in that section of what he regards as the central bank function to safeguard the condition of individual members of the banking system and to serve as the banking club manager. In section 4 we turn to Charles's discussion of the development of the central bank as the domestic lender of last resort, and in section 5 to his discussion of the need for an international lender of last resort. Some of the conclusions that he believes his studies of monetary institutions support understandably reflect a British perspective. An American perspective may differ, and in several cases we point out the differences. Section 6 concludes.

\section{Themes of His Early Research}

In his glance backward on his professional career, Charles reports that since his $1962 \mathrm{Ph} . \mathrm{D}$. thesis successfully "reinterpreted US (1900-1914) monetary history, using a high frequency data base, the obvious continuation was to try the same trick for the UK. Monthly banking data were also available (though heavily window-dressed in some respects) in the form of the monthly reports of the London Joint Stock Banks, which Chancellor of the Exchequer Goschen had required to be collected and published following the first Barings crisis in 1890. The problem was that no one had previously systematically collected, checked, and analysed these. So the better part of two years (1963/64) was then taken up with primary historical research, collecting, checking, and assembling as much monthly banking and macro-economic data as existed into usable time series format" (Goodhart 1997, pp. 395-96). 
We thus learn that from his initial research undertakings Charles was prepared to invest the requisite time and effort to construct the data base for empirical investigations, a practice he has maintained throughout his career. Having collected the data, what were the issues that Charles chose to examine?

\subsection{The U.S. Pre-Federal Reserve Gold Standard}

As indicated, the main focus of this paper is Charles's contributions to the history of monetary institutions, and his first study dealing with a pre-Federal Reserve episode when the U.S. was on the gold standard, fits in well with his broader interest. Some of the themes of Charles's later studies are already encountered in this early work. These include the role of commercial banks under the gold standard, financial crises, and the need for a lender of last resort.

For Charles, received wisdom is not to be believed before checking that it agrees with the data. He was led to revise accepted hypotheses of U.S. economists of the period 1900-1913 (E.W. Kemmerer, A.P. Andrew, and O.M.W. Sprague) about the functioning of the financial system because their interpretation of seasonal variations in interest rates "does not obtain any confirmation from the available quantitative data" (Goodhart 1969, p. 126). Specifically, their claim that interior banks withdrew their balances from New York in the fall was belied by the stability of interest rates in the interior. In addition, when other methods by which interior banks could transfer funds to and from New York were included, it turned out that interior banks actually sent money to New York during the fall rather than withdrew it. Charles concluded that the interior's favourable balance of trade during the fall improved liquidity there enough to offset increased demand for money, hence avoiding seasonal interest rate variations ${ }^{1}$. In New York, however, reduced liquidity due to payment for crops raised interest rates, which attracted a capital inflow from the interior that restored equilibrium. At the same time New York had a relatively 
favourable balance of trade with foreign countries in the fall and a relatively unfavourable balance in the summer.

Why did not trade with foreign countries offset trade with the interior? Charles's answer is that, under gold standard conditions, exchange rate variations (within the gold points) were important in the international market while in the national market they were relatively small. In international trade the autumnal export surplus raised the exchange value of the dollar towards the gold export point. This was an incentive to sell dollars or to avoid buying dollars spot and instead to buy dollars future when they would be cheaper. There was thus an offsetting short-term capital outflow, cutting down gold imports. New York did not receive cash for exports abroad but paid cash for imports from the interior. Therefore New York interest rates, especially in the call loan market, rose in the autumn relative to interest rates in the interior and in Europe. This checked the cash flow to the interior and started a gold inflow from Europe. The major disadvantage of the system was, since there was no lender of last resort, that rising interest rates could lead to a financial collapse rather than an opportunity for increased profits.

\subsection{The Pre-World War I Gold Standard in Britain}

Charles's next study was a full-fledged examination of the adjustment mechanism by which balance of payments equilibrium was achieved under the gold standard in Britain from 1891 to 1913 (Goodhart 1982). The traditional story was that the Bank of England altered Bank rate whenever its gold reserves were threatened. A rise would induce a short-term capital inflow and would check domestic economic activity, the domestic price level, and the price of imports (Cunliffe 1918). Charles proceeded to set out a series of connected hypotheses about causal relationships implied by the classical analysis of the equilibrating mechanism of the gold standard and to subject them to statistical testing. 
Testing some of the hypotheses required only Bank of England statistics; others required use of the banking data he had collected. The tests confirmed that Bank rate rises induced shortterm capital inflows. The tests failed to confirm that the domestic channel behaved in accordance with the classical analysis. The money supply process was to some extent endogenous. In response to changes in the Bank of England's gold reserve, domestic money supply changed little, and domestic economic activity changed little in response to changes in the interest rate. There was no close, positive association between commercial bank reserves, measured by bankers' balances at the Bank of England, and the Bank's gold reserves or its proportion, but they were related to the level of domestic activity.

According to Charles, the direction of causation was the reverse of that proposed by the classical analysis. Increased economic activity led to increased commercial bank lending and deposits. He reports a regression of the balance of trade surplus on a domestic activity variable for the 1890s and early 1900s that yields a significant negative coefficient. By reducing other assets the Bank of England then supplied the required increase in commercial bank reserves to maintain stable reserve ratios at commercial banks. The effect was a lower gold-reserve ratio at the Bank of England - the proportion in the banking department of the Bank -- and a higher Bank rate, which produced a gold inflow and restored the Bank's proportion. It was short-term capital inflows that permitted autonomous domestic expansion uninterrupted by monetary balance of payments disturbances.

Thus Charles's study discussed two issues that have since been at the heart of scholarly work on the operation of the gold standard: Were the external channel of adjustment by capital inflows and outflows and the domestic channel by varying domestic expenditure equally effective in restoring balance of payments equilibrium? And did central banks follow the rules of the game? According to Charles the external channel was highly effective, but he found the domestic channel ineffective, since the money supply was not responsive to changes in the Bank's gold reserves. 
In the literature on the rules of the game, different authors have variously defined them. One definition was that a central bank should reinforce the effects of payments imbalances, varying domestic credit with international reserves (Bloomfield 1959). In Dutton's view (1984), obeying the rules also meant avoiding the use of countercyclical monetary policy. He estimated the Bank of England's Bank rate reaction to several measures of its gold reserves and several measures of domestic economic conditions. To avoid the problem of two-way causality between policy tools and policy targets, he generated forecasts of the policy targets. His key finding was that Bank rate responded strongly and negatively to the Bank's reserve position, but it also responded positively to domestic economic conditions and negatively to unemployment. Countercyclical action by the Bank was a violation of the rules, a finding in accord with Goodhart's finding that the Bank varied its holdings of domestic assets independent of the level of gold reserves.

Pippenger (1984) reinterpreted Goodhart's results. ${ }^{2}$ He examined both the long-run and short-run operations of the Bank. In the short run the Bank may have accommodated domestic activity, but in the long run, it complied with rules. Its primary concern was preserving convertibility of sterling. ${ }^{3}$

So the themes that were to engage Charles in the decades after his thesis and post-doc research emerged early on. The grand theme was not only how the Bank of England's role in the financial system changed over time but also how the role of other central banks changed. It is useful to trace the development of his views on this matter and related subjects in the course of his employment by the Bank and his later academic experience.

\section{The Evolution of Central Banks}

Charles's exposure to the literature on free banking that questioned the need for and functions of central banks motivated him to examine the theoretical and historical bases for their existence (Goodhart 1985). The question he sought to investigate was whether the introduction of an agency 
to regulate and control the banking system was an undesirable intervention into what otherwise was a satisfactory free market banking industry.

Charles traced the historical basis for the creation of central banks to the financial advantage governments obtained from them, their unification of a chaotic system of note issue, their management and protection of the country's metallic reserve, and their improvement of the payments system. Once established, a central bank gained political power as the government's bank. Only later in the $19^{\text {th }}$ century did it become the bankers' bank, when commercial banks deposited their own cash reserves as balances at the central bank. Central banks, moreover, had the ability to inject liquidity by rediscounting, according to Charles, and to provide even more when the banks experienced difficulties.

Charles holds that the functions of central banks developed naturally from their relationships with the government and the banks. The functions were twofold: a macro function relating to monetary conditions of the economy, and a micro function relating to the condition of the individual members of the banking system. When central banks competed for customers with other banks, the macro function was secondary to the micro function, in Charles's view. Since no commercial competitor to a central bank could provide reserves and liquidity to other banks and regulate them, historic central banks founded before the $19^{\text {th }}$ century that began as a competitive, profit-maximising institution alongside many others had to change to a non-competitive non-profit maximising one if they were to exercise their micro function. Central banks founded at later dates that began as non-competitive, non-profit maximising institutions have been readier to leave the micro function of supervision to separate government bodies (Goodhart and Schoenmaker 1995). In his survey of the objectives and functions of 32 central banks, arranged chronologically by date of founding, he distinguishes the evolution from the original objectives and functions and traces the changes in the degree of their independence (Capie, Goodhart et al. 1994) 
The development of historic central banks in Charles's account occurred in three stages. They began as government banks. They then also had commercial profit-maximising banking interests. They remain the governments' bankers throughout, and governments may dominate their objectives and policy actions. At a second stage historic central banks relinquished their commercial interests and became bankers' banks, devoting themselves to the welfare and safety of their former rivals, individual commercial banks, and to the financial system in general. A question that Charles considers is whether this purpose requires the central bank to undertake regulation and supervision of the financial system or whether a separate financial supervisory authority should shoulder the job. The commercial banks initially form a club that the central banks manage, but as dividing lines between different kinds of financial intermediaries become blurred, the club feature declines.

Historically, the institutions founded in the $19^{\text {th }}$ century that gradually transformed themselves into central banks enjoyed relative independence from government but were constrained in their potential for conducting independent policy by the commitment to convertibility. That independence ended with the advent of the First World War, according to Charles and his coauthors (Capie, Goodhart et al., 1994, p. 49). ${ }^{4}$ We note that some central banks retained their independence until the Great Depression undermined it. Only recently has the trend begun to be reversed. So there is now a third stage in the development of central banks as they gain independence from governments, which may retain the right to define the objectives but delegate to central banks the choice of instruments to achieve them.

We summarise further each stage of central bank development that Charles describes.

\subsection{The Central Bank as Government Bank}

Central banks, established by government charter, have invariably been designated as the governments' banker. Governments naturally seek cheap finance from their banker, especially 
during wars or similar types of crisis. In those circumstances central banks have had to subordinate whatever objectives they might otherwise have sought to pursue - convertibility, price stability, economic growth -- to their government's wishes. Extricating themselves from subservience to the government has usually entailed a political struggle over an extended period. Charles and his coauthors (1994, pp. 48-63) discuss three determinants of the relationship between central banks and governments: peace or war, the dominant political philosophy - laissez faire in trade and monetary matters, or state economic management - and the exchange-rate regimes - the gold standard, for example, viewed as a single central bank objective that diminished the state's role. The influence on the relationship of the government and the central bank of exchange-rate regimes other than the gold standard is not discussed by the authors.

\subsection{The Central Bank as Bankers' Bank}

For Charles, a core function of central banks is concern for the well-being of the banking system inclusive of the payments system. This priority becomes possible when two developments occur: the central bank does not compete with commercial banks for customers and profit and commercial banks deposit their reserves at the central bank. Because of this concern, central banks or a surrogate exercise supervisory and regulatory responsibilities.

The concern arises because Charles (1991) regards commercial banks as inherently unstable. They are imprudent lenders and investors, in need of outside direction and protection. Banks exist to make loans to small- and medium-size borrowers with no access to capital markets. Financial markets for them are incomplete, so bank loans are substitutes for non-existing markets. The reason a financial market does not exist is that information is unavailable on the prospects of the projects for which borrowers seek loans. Indeed, there is information asymmetry in the bankercustomer relationship, since the borrower knows more about the likely outcome of his project than does the commercial bank. According to Charles, bankers also exhibit herd-type behaviour that 
leads to periods of overexpansion culminating in financial crises followed by periods of retrenchment and recession.

Central banks may not be wiser than commercial banks, Charles acknowledges, but should be able to check and limit contagious crises that arise. Moreover, central bank regulation can prevent imprudent bank behaviour that leads to banking crises.

Questions may be raised concerning Charles's views on bank instability and on the contagious effects of an illiquid or insolvent bank on other liquid or solvent banks. It is arguable that instability does not inhere in banks since they can hold prudent reserves and adequate capital. Instead, unstable monetary policy and bad regulatory actions produce unstable banks. Moreover, only under exceptional bank panic conditions, does evidence support the belief that distress and failure of individual financial firms is a threat to the system as a whole. Contagion is rare, not endemic (Benston and Kaufman 1995).

In addition, Charles's view that a central bank exists to provide special assistance to individual banks by discount window lending has been challenged (Goodfriend and King 1988). Open market operations that provide liquidity to the market are sufficient to take care of the needs of solvent institutions with liquidity problems. A central bank can shut down the discount window in the knowledge that its open market operations can accommodate the system and the market will allocate the reserves it creates to individual banks that require an infusion.

Charles emphasises two other aspects of the central bank-commercial bank symbiosis: commercial banks need a central bank to serve as their lender of last resort (discussed in section 4), and commercial banks under central bank leadership operate like a club, in order to control the conduct of their members; the aim of control he believes to be guaranteeing quality of service to depositor-customers. However, commercial banks operate like a club even in the absence of a central bank, e.g., Canada before 1935. 
Free banking proponents on the other hand advocate self-regulation by the club members. In Charles's view, that course is incompatible with conflicts of interest among banks, so he rules out a voluntary club with an independent arbiter. What emerges instead is an official body - the central bank, or alternatively, according to Charles, a private clearing house -- to run the system with a legally imposed set of rules. As the supervisory agency the central bank or clearing house sets the terms of entry into the club and rules of behaviour. Terms of entry, of course may be set by a clearing house, but terms of entry into the banking system are not determined by the central bank but by a chartering agency. In the US the agency may be state or federal. In addition, a clearing house in the U.S. had no legal power. It was a private organisation with no official standing.

Associated with the club, before there was a central bank, there was a private clearing house to provide support to member banks that needed help. Although Charles recognises the need for a club manager, he asks whether a body less powerful than current central banks could not do the job.

\subsection{Central Bank Independence}

We indicated above that we do not agree with Charles's view that central bank independence ended with the First World War. Some central banks in fact retained independence until the Great Depression. He, nevertheless, holds that it was inconceivable in the decades following the war. The monetary authorities after all were both the central bank and treasury. Charles asks, What changed the climate of opinion thereafter? His answer is that the campaign for independent central banks in recent decades has been supported by theoretical arguments and empirical evidence. The working definition of independence that Charles and his co-authors adopt is "the right to change the key operational instrument without consultation or challenge from the government" (1994, p. 50). The government, however, chooses the objective the central bank is mandated to fulfill. They regard the recent debate on central bank independence as having settled on the use of the central bank's single main instrument in the light of its own discretion for the generally agreed objective - medium-term 
price stability. Other questions have become subsidiary - accountability and management structure -- to which independent central banks give different answers. They caution that independence may be oversold as the solution to monetary ills.

\section{The Central Bank as Domestic Lender of Last Resort}

A traditional monetarist view is that the role of a lender of last resort is to prevent or check banking panics by injecting funds into the banking system. Charles disagrees. He argues that convertibility of deposits into currency is not the key feature of banking panics that a central bank exists to prevent. It is rather the fact that any major shift of deposits within the banking system (from banks perceived to be weak to banks perceived to be strong) will be destabilising. The reason is that the transfer of deposits is much easier than the transfer of bank loans. "It is the collapse of the borrowing relationships, as failing banks call in loans, leaving borrowers without the ability to replace the money at all easily or reasonably quickly, that is at least as responsible, as the loss of the depositors' wealth, for the resulting dislocation" (Goodhart n.d.) ${ }^{5}$.

From an American viewpoint, two questionable assumptions underlie Charles's argument. One is the loss of depositors' wealth that is contrasted with the loss of borrowers' bank relationship. In fact, the real contrast that he should have drawn is between bank failures that destroy the money stock and bank failures that destroy the bank-customer relationship. We note that destruction of the money stock affects every market in which money is used. And it is not at all inevitable that bank failures destroy the relationship for reorganised banks may operate with the same management. Charles's second assumption about a special relationship between the bank and the borrower is that what inhibits establishing a new relationship with another bank is the cost to a bank to obtain information known privately only to the borrower. ${ }^{6}$ Many borrowers in the U.S., however, have relationships not just with one source of funds - banks, insurance companies, factors - but with several of each. More importantly, banks to which deposits have been transferred are surely eager 
to invest the funds. Why would borrowers of good standing not find a responsive lender in the circumstances?

Charles (1999) regards Bagehot's prescription for a lender of last resort to lend freely at a penalty rate on good collateral to be hopelessly out of date. What Bagehot also stressed was that a central bank should leave no uncertainty about its intention to provide assistance. Charles believes that central banks nowadays do not conform to Bagehot's rules. He regards the ability of central banks to distinguish cases of illiquidity from those of insolvency as a myth. The reason is that a central bank faces difficulties in valuing the assets of a bank seeking assistance, so cannot know whether it is insolvent rather than illiquid. Advising a central bank to lend only to illiquid banks, in Charles's view, is facile and unworkable. It is not clear what the circumstances are that Charles has in mind. Is this a problem for a central bank when it is approached for a discount window loan by single banks? (On the frosted window at the Bank of England that obscures the identity of the borrower, see Capie (2001). Or does the problem arise under panic conditions when many banks seek assistance?

As Geoffrey Wood (2000) has noted, Hawtrey (1932) long ago disposed of Charles's view that it was impossible for a central bank to distinguish between illiquidity and insolvency. Hawtrey explained that it was a bank's ability to furnish collateral more than sufficient to cover a central bank loan that made it unnecessary to judge the bank's solvency.

In the U.S., where regulators grade banks on their performance according to a scale of 1 to 5, the grades based on 5 measures known by the acronym of CAMEL (Capital adequacy, Asset quality, Management, Earnings, Liquidity), there is no difficulty for the Fed to distinguish between an illiquid and an insolvent bank (see Schwartz 1992).

With respect to penalty-rate lending and collateral requirements in accordance with Bagehot's prescriptions, one commentator suggests that they are observed as far as ordinary last- 
resort operations are concerned but not in the case of "truly extraordinary" operations (Giannini 1999, p.14). He does not, however, define the latter.

Charles also accepts another buzz phrase associated with the new view of the way a lender of last resort operates -- creative ambiguity. Far from assuring the market that it will with complete certainty provide assistance, the new view of a lender of last resort is that it should leave the market in doubt about its intentions. The defence of this approach is that it lessens moral hazard that would otherwise increase the likelihood of crises and financial instability (Giannini 2001 ). Yet the incidence of panics and crises declined while Bagehot's teachings prevailed. What successes can the new view claim? Does the failure to observe Bagehot's rules validate central bank waywardness? Charles passes judgement neither on central bank nor regulators' behaviour. Whatever they do is deemed to be right conduct.

Charles refers to "relief operations during crises" (Goodhart 1985, p. 51). During crises, he asserts, a central bank does not have sufficient resources to be able to manage them out of its own funds. This may have been the case under the gold standard, when the Bank of England's gold reserves were scanty, but that cannot be the case under a fiat money regime.

The assistance by a consortium that the Bank of England organised to rescue Barings in 1890, one should remember, was to save an illiquid but a solvent bank. The fear that actuated support of the bank was that its failure might have prompted an external gold drain. No single bank had the resources to overcome Barings' shortage . Hence the grounds for the need for concerted action in this case differ from the circumstances that Charles alludes to to justify concerted action generally.

It is odd to describe a central bank in today's regime as short of sufficient resources. What distinguishes a central bank from other authorities is its ability to create unlimited amounts of the monetary base and subsequently to withdraw them. So currently insufficient resources cannot be the ground for a central bank to encourage other commercial banks to participate in rescues. An 
exception may be an emerging market country that lacks credibility and has a huge proportion of bank deposits in foreign currency so that open market operations in domestic currency will be insufficient and may lead to capital outflow.

Nevertheless, Giannini (1999) cites two reasons that resource availability may be a problem. First, the central bank may lend to a bank that in the end becomes insolvent and is unable to repay its borrowings. Second, emergency lending may conflict with monetary policy. These are not compelling reasons in a fiat money regime, but Giannini believes that they account for concerted lending -- rescue operations conducted by a small group of banks including the central bank. Concerted lending, he says, involves a redistribution of existing reserves instead of the creation of additional amounts, exemplified, according to Giannini, by the $19^{\text {th }}$ century US clearing house system. But he is mistaken in claiming that clearing house rescues merely redistributed existing reserves. Clearing houses created additional amounts on the basis of collateral supplied by member banks. Concerted lending has less to do with resource limitations than with the new view that it is a virtue for the authorities to involve the institutions that comprise the financial system in crises situations.

Concerted lending has been the rule in 104 bank crises in the 1980s and 1990s (Goodhart and Schoenmaker 1995). In only two cases did a central bank undertake a rescue on its own. The Fed, however, has not sought assistance from the domestic financial community in the past decade in resolving crises (Giannini 1999, p.7). Its intervention in dragooning concerted lending by LTCM's financial backers in the 1998 Russian default crisis did not involve a monetary contribution by the Fed.

In any event, we question the case that Charles makes that rescuing an insolvent institution should be a central bank responsibility. An insolvent bank requires recapitalization or termination. A central bank has no responsibility to provide capital for financial institutions. If fiscal authorities 
believe that the financial system would be impaired by the failure of a large insolvent institution, they rather than the monetary authority should do the bailout.

\section{An International Lender of Last Resort?}

If the rationale for a domestic lender of last resort is that one is needed to prevent or offset a shift of deposits within the banking system, then by analogy Charles argues that an international lender of last resort is needed when there is a major shift of funds from one country to others. He advocates restoring the funds to the country from which they have fled. Should one advocate such a move whether or not policy reform has been implemented if misguided policies of the country in question occasioned the capital flight?

Goodhart and Huang (2000) build an open economy model with several economies in the Diamond-Dybvig genre. They analyse conditions under which international financial contagion emerges that provides a useful role for an international lender of last resort. In the model the central bank in each economy uses foreign reserves to maintain a pegged exchange rate. Each economy has a banking system with domestic and international depositors, both with domestic currency deposits, but international depositors convert withdrawals into foreign currency. A central bank can prevent a domestic liquidity crisis but, in the absence of an international lender of last resort, a foreign currency liquidity crisis can trigger both a domestic liquidity crisis and a domestic banking crisis. If the economies are linked by an international interbank market, it may be able to provide needed liquidity. However, if liquidity in the interbank market were not adequate to save all illiquid banks, some banks would face a currency run which could trigger a domestic banking crisis. The failure of one bank informs all depositors in every bank and economy that the international interbank system has exhausted its available liquidity. An international currency crisis ensues that triggers an international banking crisis. The conclusion is that an international lender of last resort can provide international liquidity and reduce international contagion. 
We ask Goodhart and Huang to explain how there can be an international lender of last resort when there is no single central bank acting as the global world's monetary authority. An existing international financial institution cannot create high-powered money in any national currency, so it cannot create international reserves. Goodhart and Huang, moreover, do not define the attributes of an international lender of last resort that they have in mind. As for their assumption of international financial contagion, actual examples of multi-country financial disturbances during the 1990s illustrate not contagion but capital flight from countries with similar unsustainable policies.

Discussion of an international last-resort lender inevitably applies to the IMF. It is acknowledged that extension of its role to the international domain encounters severe problems (Giannini 1999, p. 39). Limited resource availability, however, is said not to be a key problem. The latest IMF quota increase, the increases in GAB-NAB, and the possibility of activating bilateral contributions, the argument goes, indicate that the IMF can mobilise resources in case of need. The real problems are said to be more fundamental.

One fundamental problem the international last-resort lender will encounter is the risk of politicisation of its rescues so that they serve the interest of stronger countries rather than the collective interest. ${ }^{7}$ Another problem is that the international lender has limited enforcement powers. Finally, international creditors are not subject to the control of international organisations whereas national authorities have some control over domestic creditors. Therefore a universal lender of last resort is likely to suffer from important weaknesses. And the suggestion to transform the IMF into a Bagehotian lender of last resort would risk creating an unacceptable degree of moral hazard (Meltzer Commission 2000).

Given these obstacles facing a would-be international lender of last resort as described by someone sympathetic to such a function, we question that there is a need for IMF lending (Fischer 1999). The widening and deepening of capital markets in recent decades have established them as 
willing providers of loans to creditworthy countries. The internal problems of emerging market countries that have gotten them into trouble in the 1990s can be solved not by the IMF but only by the countries themselves and the actions of their national central banks.

\section{Conclusion}

In assessing Charles's contributions to the history of monetary institutions, it is noteworthy that the views he has espoused are widely recognised as uniquely his. Many economists believe that banks are fragile but only Charles has defined that fragility in terms of the asset side of their balance sheets. Also associated with Charles is the description of banks as operating like a club. His emphasis on the micro rather than macro function of central banks is again special to Charles. Most students of central banking would assign a more important role to the monetary policy function than he does. That regulation and supervision are central to Charles's concerns reflect his belief in the fragility of banks.

Despite the special nature of Charles's approach to the foregoing matters, he has been a mainstream economist, who finds evidence that markets fail more readily than that policy makers and regulators fail. He has applied this philosophy to the history of central banks and other institutions.

One of the interesting features of Charles's work as a mature student of monetary institutions is the dialogue he has conducted throughout with the free bank proponents. A mainstream economist, he more than anyone else has given their views a hearing. What is even more interesting is to juxtapose his and their views. They are opposites. Free bank proponents believe private banks are stable institutions that have a self-interest to be conservative lenders who scrupulously honour their promises to redeem their monetary liabilities at par, in the past redeemed their monetary liabilities in gold or foreign exchange without devaluation, were self-regulated, and 
that central banks were not only not needed but also were unreliable in fulfilling their commitments to redeem domestic currency at par.

Charles's views are diametrically different. Banks are unstable, periodically either overissuers or underissuers, unless constrained by regulators and central banks, which are essential even if not exemplary performers. Charles's views emerge from a rich familiarity with the nuances of financial markets in the past as well as their very latest manifestations. In this regard, free bank proponents appear to be dependent on selective elements of past financial history and not at all well grounded in contemporary financial developments. In this contest Charles is clearly the winner. Yet Charles may well have been influenced by the free bank literature to the extent that he has acknowledged the shortcomings of central bank performance. At the same time he has been an ardent advocate of the indispensable role of central banks as regulators and supervisors of the financial system and as providers of lender of last resort funds. Although we do not see eye to eye with Charles on issues he has addressed, we are happy to participate in the tributes to his labours in the vineyard of monetary institutions. 
Notes

${ }^{1}$ See Miron (1986) on seasonal movements in nominal interest rates before 1914 and their elimination after 1914 by seasonal open market operations by the Fed.

${ }^{2}$ Subsequent research employs newer techniques to deal with the Bank of England pre-World War 1 gold standard rules of the game -Giovannini (1986), Jeanne (1995), Bordo and MacDonald (1997) - but also with the interwar gold standard - Davatyan and Parke (1995), Eichengreen, Watson, and Grossman (1985) - and with the pre-World Warl Reichsbank - Eschweiler and Bordo (1994).

${ }^{3}$ As the discussant of the papers by Dutton and Pippenger on Bank of England behavior under the pre-World War I gold standard, Goodhart defended his own views.

He argued (1984) that what is at issue is not the actual way that the Bank operated but the interpretation of the reasons for its behavior. He regards the fundamental objective of the Bank in unusual circumstances was "the maintenance of the basic fabric and structure of the banking and financial system." Under normal circumstances the most important function of the Bank was to protect convertibility. He offers two possible interpretations of its behavior. One is that there was a tradeoff in objectives: for a given loss of reserves, the Bank would raise Bank rate by more if domestic activity was higher than if it was lower. Another interpretation is that the state of domestic activity served as an indicator of risk of future gold drains, either internal or external, from its reserves. Goodhart cites statements by both Pippenger and Dutton in support of his finding that the Bank provided some accommodation of monetary changes to domestic activity. He notes three differing views to explain the Bank's behavior. Dutton attributes it to inertia during periods when interest rates are fixed. Pippenger attributes it to concerns to maintain profits. Goodhart attributes it to concern with market share and profit when the Bank's size fell progressively relative to the size of the joint stock banks. He doubts that the Bank was consciously trying to support the needs of trade. 
${ }^{4}$ The text reads: "A considerable degree of independence therefore obtained [before the First World War], particularly in so far as it related to the central bank assisting in the smooth working of the gold standard. The period from the First World War to the 1970s has in contrast been the age of the state, of economic management, of socialism. It was in this period that there was a move to greater government control, and of more dependent central banks."

In discussing our paper at the Conference, Forrest Capie claimed that the text did not support our statement that, according to the authors, the loss of central bank independence dated from 1914 . He cited a paragraph on p. 53, which does refer to "the pursuit of independence" in the years to the Great Depression. The ambiguity is unresolved.

${ }^{5}$ The same point appears in Goodhart (1987) but not the quoted sentence.

${ }^{6}$ Goodhart's view is related to but not the same as that of Bernanke (1983) that widespread bank failures raise the cost of financial intermediation.

${ }^{7}$ The record of recent IMF rescues suggests that such efforts have not always led to prompt recovery (Bordo and Schwartz 2000). 


\section{References}

Benston, George J. and George G. Kaufman (1995), 'Is the Banking and Payments System Fragile?' Journal of Financial Services Research 9 (3/4), (December), 209-240.

Bloomfield, Arthur I. (1959), Monetary Policy Under the International Gold Standard, New York: Federal Reserve Bank of New York.

Bordo, Michael D. and Ronald MacDonald (1997), 'Violations of the 'Rules of the Game' and Credibility of the Classical Gold Standard, 1880-1914,' NBER Working Paper 6115 (July).

Bordo, Michael D. and Anna J. Schwartz (2000), 'Measuring Real Economic Effects of Bailouts: Historical Perspectives on How Countries Fared With and Without Bailouts,' Carnegie Rochester Series on Public Policy 53 (December), 81-167.

Calomiris, Charles W. ( 1998), 'The IMF’s Imprudent Role as Lender of Last Resort.' Cato Journal 17 (3), 275-295.

Capie, Forrest (forthcoming 2002), 'The Emergence of the Bank of England as a Mature Central Bank,' in Donald Winchard and Patrick O'Brien (eds.), The Political Economy of British Historical Experience, 1688-1914, Cambridge University Press.

Capie, Forrest, Charles Goodhart, Stanley Fischer, and Norbert Schnadt (1994), The Future of Central Banking: The Tercentenary Symposium of the Bank of England, Cambridge: Cambridge University Press.

Cunliffe (1918), First Interim Report of the Committee on Currency and Foreign Exchanges After the War, UK Parliament, Cmnd. 9182.

Davatyan, Nathan and William R. Parke (1995), 'The Operations of the Bank of England, 18901908: A Dynamic Probit Approach,' Journal of Money, Credit, and Banking 27 (4) (November, Part 1), 1099-1112. 
Dutton, John (1984), 'The Bank of England and the Rules of the Game under the International Gold Standard: New Evidence,' in M.D. Bordo and A.J. Schwartz (eds.), $\underline{\text { A Retrospective on the }}$ Classical Gold Standard 1821-1931, Chicago: University of Chicago Press, pp. 173-202.

Eichengreen Barry, Mark W. Watson, and Richard S. Grossman (1985), 'Bank Rate Policy Under the Interwar Gold Standard: A Dynamic Probit Analysis,' Economic Journal 95 (September), 725-746.

Eschweiler, Bernard and Michael D. Bordo (1994), 'Rules, Discretion, and Central Bank Independence: The German Experience, 1880-1989,' in Pierre Siklos (ed.), Varieties of Monetary Reforms: Lessons and Experience on the Road to Monetary Union, Boston: Kluwer Academic Publishers.

Fischer, Stanley (1999), 'On the Need for an International Lender of Last Resort,' Journal of Economic Perspectives 13 (4) (Fall), 85-104.

Giannini, Curzio (1999), 'Enemy of None But a Common Friend of All? An International Perspective on the Lender of Last Resort Function,' Essays in International Finance, no. 214, (June), Princeton: Princeton University.

Giannini, Curzio (2001), 'Pitfalls in International Crisis Lending,' in Charles Goodhart and Gerhard Illing (eds.), Financial Crises, Contagion, and the Lender of Last Resort: a Book of Readings, Oxford: Oxford University Press.

Giovannini, Alberto (1986), 'Rules of the Game During the International Gold Standard: England and Germany.’ Journal of International Money and Finance 5 (December), 467-483.

Goodfriend, Marvin and Robert G. King (1988), 'Financial Deregulation, Monetary Policy and Central Banking,' in W.S. Haraf and R. M. Kushmeider (eds.), Restructuring Banking \& Financial Services in America, Washington, DC: American Enterprise Institute.

Goodhart, Charles A. E. (1969), The New York Money Market and Finance of Trade, 1900-1913, Harvard Economic Studies, v. 132, Cambridge, MA: Harvard University Press. 
Goodhart, Charles A. E. (1972), The Business of Banking 1891-1914, London School of Economics and Political Science.

Goodhart, Charles A. E. (1984), 'Comment,' in M.D. Bordo and A. J. Schwartz (eds.), $\underline{A}$ Retrospective on the Classical Gold Standard 1821-1931, Chicago: Chicago University Press, p. 227.

Goodhart, Charles A. E. (1985), The Evolution of Central Banks, London School of Economics and Political Science.

Goodhart, Charles A. E. (1987), 'Why do Banks Need a Central Bank,' Oxford Economic Papers $39,75-89$.

Goodhart, Charles A. E. (1991), 'Are Central Banks Necessary?’ in Forrest Capie and Geoffrey E. Wood (eds.), Unregulated Banking: Chaos or Order? London: Macmillan.

Goodhart, Charles A. E. (1993), 'Institutional Separation between Supervisory and Monetary Agencies,' in F. Bruni (ed.), Prudential Regulation, Supervision and Monetary Policy, Universita Commerciale Luigi Bocconi, pp. 353-439.

Goodhart, Charles A. E. (1997), 'Whither Now?’ Banca Nazionale del Lavoro Quarterly Review 50 (December), 385-430.

Goodhart, Charles (1999), 'Some Myths About the Lender of Last Resort,' International Finance 23, (November), 339-360.

Goodhart, Charles A.E. (n.d.), 'Why Do We Need a Central Bank?’ Processed.

Goodhart, Charles A.E. and Haizhou Huang (2000), 'A Simple Model of an International Lender of Last Resort,' IMF Working Paper, WP/00/75.

Goodhart, Charles and Dirk Schoenmaker (1995), 'Should the Functions of Monetary Policy and Bank Supervision Be Separated?' Oxford Economic Papers 47, October.

Hawtrey, Ralph G. (1932), The Art of Central Banking, London: Longmans, Green \& Co. 
Jeanne, Olivier (1995), 'Monetary Policy in England 1893-1914: A Structural VAR Analysis,' Explorations in Economic History 32, 302-326.

Meltzer, Allan H. et al. (2000), Report, Washington, D.C.: International Financial Institution Advisory Commission of the U.S. Government.

Miron, Jeffrey A. (1986), 'Financial Panics, the Seasonality of the Nominal Interest Rate, and the Founding of the Fed,' American Economic Review 76 (March), 125-149.

Pippenger, John. (1984), 'Bank of England Operations, 1893-1913,' in M.D. Bordo and A.J. Schwartz (eds.), A Retrospective on the Classical Gold Standard 1821-1931, Chicago University Press: Chicago, pp. 203-221.

Schwartz, Anna J. (1992), 'The Misuse of the Fed's Discount Window.' Federal Reserve Bank of St. Louis, Review 74 (5) (September-October), 58-60.

Wood, Geoffrey E. (2000), 'The Lender of Last Resort Reconsidered.' Journal of Financial Services Research (18 2/3) (December), 203-227. 